\title{
Decision on the Devonian-Carboniferous boundary stratotype
}

\author{
The Global Stratotype Section and Point for \\ the Devonian-Carboniferous boundary has been \\ agreed upon now. The boundary is defined in trench \\ $E^{\prime}$ at La Serre in the southeastern Montagne Noire, \\ France.
}

\section{Introduction}

The Working Group on the Devonian-Carboniferous Boundary was established in 1976 by the International Commission on Stratigraphy (ICS). Its first field meeting visited 22 localities in northwestern Europe in 1978. One of the most impressive experiences of that 10-day trip was the opportunity to compare depositional environments that ranged from bathyal to continental and had rates of sedimentation that were more than 100 times greater in some areas than in others. It was apparent that obvious or inferable discontinuities were present in almost all the sections we visited.

The conclusion reached on our field trip in 1978 was confirmed during highly detailed research that was carried out on sediments and fossils near the Devonian-Carboniferous boundary in Europe. Asia, Africa, Australia, and America in succeeding years (Paproth and Streel, 1984; Flajs and others, 1988). The position of the boundary in the biostratigraphic sequence was established near the "classic" base of the Gattendorfia Zone: "This new definition is at the first appearance of the conodont Siphonodella sulcata within the evolutionary lineage from Siphonodella praesulcata to Siphonodella sulcata. . ." (Paproth and Streel, 1984. p. 5). This recommendation was submitted by R.H. Lane (USA). C.A. Sandberg (USA), and W, Ziegler (Germany) and was accepted in 1979 by the working group. The following 9 years were spent searching for a section that shows this evolutionary lineage. Both species occur worldwide but ate restricted to pelagic facies.

In 1983 the working group recommended that work be concentrated on four sections: Hasselbachtal (Germany). Muhua (China). and $\mathrm{Kija}$ and Berchogur (USSR). The two in the USSR were dropped later for various reasons. In 1983 Hasselbachtal was chosen provisionally as a Global Stratotype Section and Point (GSSP). However, the final decision was postponed in order to reconsider the sections, as none of them was ideal because of the discontinuities of sedimentation and fossil transition near the boundary. The group planned to meet again in a "conclave" in May 1988 in Courtmacsherry, southem Ireland, for the purpose of finalizing the decision.

After a few years of seeming apathy, fout more sections were proposed as possible candidate stratotypes following a "last call for candidate stratotypes." which was published in 1985 in several journals. The morits of these four sections were fiercely contended, an experience already described by Hedberg (1976. p. iv). These sections were Nanbiancun (China: Yu, 1988), La Serre (France; Feist and Flajs, 1987; Flajs and Feist, 1988). Drewer (Germany; Clausen and others. 1987. 1989 (addicional description)). and Grüne Schneid (Austria; Schönlaub and others, 1988)

By the conclave meeting in May 1988. appropriate descriptions and documentation had been published or otherwise brought to the attention of the working group for only four of the six candidate sections: Nanbiancun (Yu. 1988). Hasselbachtal (Becker and others. 1984), Muhua (Hou and others, 1984), and La Serre (Flajs and Feist. unpublished manuscript). Although the date and decisive character of the conclave meeting had been known for about 4 years in advance. not all the competing specialists succeeded in attending the meeting Nevertheless, outstanding specialists, members, and nonmembers of the working group thoroughly discussed the sections and fossils submitted to them. The specialists who were present voted on it "package." as follows: La Serre section. at the base of bed 89. is ti be a Global Stratorype Section and Point, because it was the only section where "the first appearance of the conodont Siphonodello sulcata within the evolutionary lineage from Siphonodella pratesucata to Siphonodella sulcata" has been observed, the Hasselbachtal section and the Nanbiancun section being Auxiliary Stratotype Sec. tions (Cowie and others. 1986, p. 5).

A postal ballot of the working group membership confirmed the above choice on 1 September 1988. The "Proposal of the Global Stratotype Section and Point (GSSP) for the Devonian-Carboniferous Boundary" was sent to the ICS and the International Union of Gcological Sciences (IUGS) for acceptance and ratification in January 1989. During the ICS meeting in Washington, D.C.. USA, in July 1989, La Serre section was accepted by that body. and in February 1990, it was accepted by IUGS.

La Serre section is far from being an ideal GSSP, but it was the only section known at the time that showed the "cvolutionary lineage of Siphonodella praesulcata to Siphonodella sidcata." The inconveniences of La Serre section. such as the lack of some other important stratigraphic guides (for example, cephalopods, spores, and ash lay. ers for radiometric dating) and the existence of reworking, induced the working group to support La Serre section by the Auxiliary Stratotype Sections of Hasselbachtal and Nanbiancun. These two meticulously described sections confirm and guarantee without any reasonable dnubt the right position of the Devonian-Carboniferous boundary at the base of bed 89 in La Serre.

Another Chinese stratolype candidate (Dapoushang) was pre sented in 1989 (Ji Quiang and others. 1989). It seemed to have disadvantages sinilar to those of the nearby Muhua section, which hatd been given up earlier. The section cante to the knowledge of the working group only after the decisive vote

In summary, the experience of 12 years of study of this welldefined, short timespan from many parts of the world has taught us that no rock succession is or can ever be a complete representation of time; only a quick change of life (fossils) and environment (rocks. permits the worldwide correlation and recognition of beds of a defined age; these inevitable "irregularities" in fossil and rock sequences cause difficulties in finding suitable stratotype sections: and the political and psychological difficulties in determining stratotype boundaries shouid not be underestimated. 


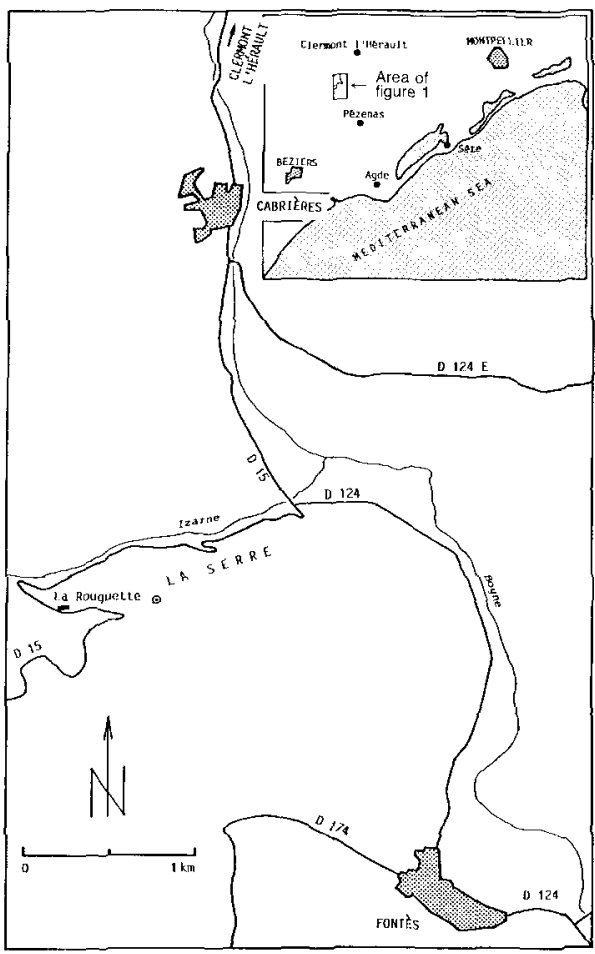

Figure I.-Inset showing southern France and geographic location of La Serre hill and vicinity.

Titular Members of the working group for all or parts of its existence are M.J. Bless. 1. Chlupác. B.F. Glenister, H. Holland M.R. House, L.I. Kononova, M. Lys, B.L. Mamet, E. Paproth. G. Playford, F.A. Reitlinger. C.A. Sandherg, P. Sartenaer, G.D. Sevastopulo. K.V. Simukov. M. Streel. Wang Chen-Yuan, and W. Ziegler.

\section{Boundary stratotype (GSSP)}

La serre section is siluated jn the southeastern Montagne Noire, Département Hérault, District of Cubrieres, southern France ifigs. 1. 2). The rocks in the trench, as well as all of La Sarre hill and vicinity, are part of the geologic unit named "Klippen of Cabrieres." Artificial trench E', which averages $80 \mathrm{~cm}$ in depth on the southern slope of La Serre hill, is about $125 \mathrm{~m}$ south of the hilltop $(252 \mathrm{~m})$, :bout $525 \mathrm{~m}$ cast of La Rouquelte farmhouse. $2.5 \mathrm{~km}$ southwest of the village of Cabrières. $2.5 \mathrm{~km}$ northeast of the village of Fonteेs,

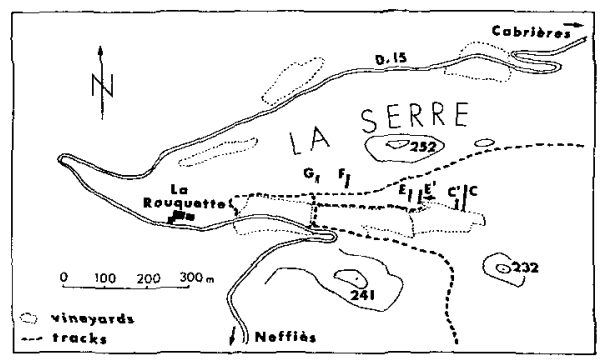

Figure 2. - La Serre hill and the trenches $\left(E^{*}=G S S P\right)$ near La Rouquette farmhouse south-southwest of the village of Cabrières.

and about $7 \mathrm{~km}$ northeast of the village of Neffies (sheet 1:25,000 Pézenas XXVV/44, 1-2. $x=682.55 . y=140.12\}$. The rench exposes about $35 \mathrm{~m}$ of "boundary beds" in a dipping section (figs. 3-5). The individual beds, which can be followed laterally, dip $70^{\circ}$ to the south. They are not overturned, and schistosity and tectonic complications are absent.

Easy access is possible from Route Départementale D 15. There are no political or geographical problems of acess. The area is macchia land " garrigue," typical atrid Medjterranean vegetation including sclerophyllous evergreens and thorn thickets, that is, Ulex, Cisins, Jumiperus t, and famland use is not possible. The site cannot be overbuilt. The landowner. M. Rene Roux of La Rouquette farm, accepts the protection of La Serre site. The Cabrieres officials are ready to apply for complete protection as a "site classé" at the departmental level.

The Devonian-Carboniferous boundary bedk are described in detail by Engel and ofhers (1982). Feist and Flajs (1987). Flajs and Feist (1988), Legrand-Blain and Martinez Chacon (1988). SemenoffTian-Chansky (1988), and Vachard (1988). These descriptions include location maps, columnar diagrams, and profiles showing relevant sedimentological and paleontological (fig. fi) data.

The presence of wockluneriics indicates the upper Paratocklameria paradosa Zone for the topmost layers of the platy and nodular cephalopod-bearing limestones that are found below the oolite units. These layers can be correlated with the upper part of the lower Siphonodella procsulcata Zone, as Preudopolygnathus marburgensis trigonicks occuts without protognuthodids. The index fossil S. praesulcata enters the section together with the first protognathodids. such as Protognathodis collinsoni and meischneri, in the fower oolite urit at beds 73 and 70 , respectively. This index fauna is joined by Protognathodius kockeli and transitional forms betwcen $S$. pracsulcata and $S$. sulcata at the base of the upper oolite unit (bed 85), which indicates an age at the beginning of the upper $S$. praesulcata Zone. Undoubted morphotypes of $S$. sulcata first occur in bed 89. at the base of which the actual GSSP is defined accordingly.

One single siphonodellid fragment from bed 85 is problematic. as it is controversially considered by Cowic and others (1989) to be a rypical representative of 5 . sulcata. However, the slight longitudinal arch and the narrow symmetrical outline of the platform adjacent to the carina, which presents a "broken" curvature, are untypical features following the revised diagnosis and figures given by Sandberg and others (1972) (the holotype of $S$. sulcata is lost). This specimen, therelore. has been regarded als representing an internediate morphotype between $S$. praterulcata and $S$. sulcata. 


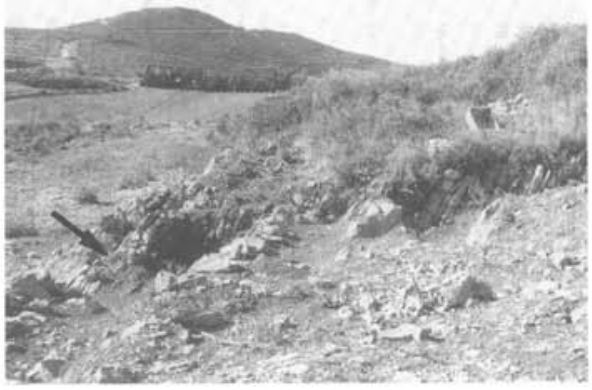

Figure 3.-View from the east looking at the stratotype section (La Serre trench $E^{\prime}$ ) that contains the Devonian-Carboniferous boundary GSSP (arrow). The box is $30 \mathrm{~cm}$ in width.

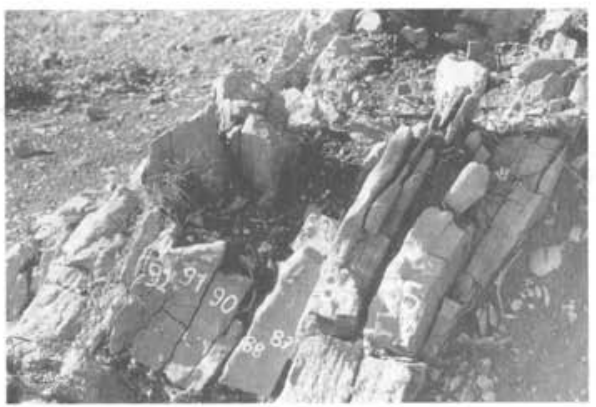

Figure 4.-Closeup view of the upper oolite unit showing the position of the GSSP between the top of bed 88 and the base of bed 89. The number " 90 " is $4 \mathrm{~cm}$ high.

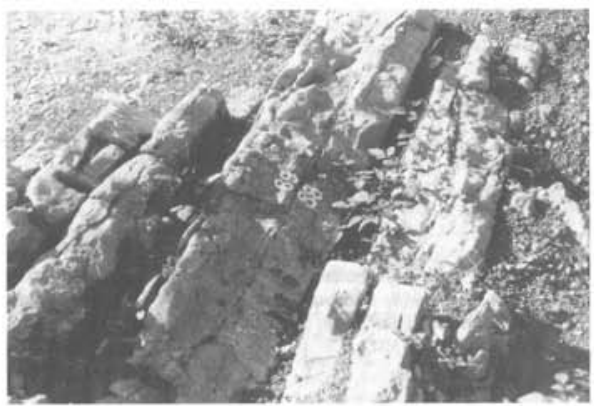

Figure 5. - Superposition of boundary beds 88 and 89 in complete continuity to the west of the GSSP. The numbers are $4 \mathrm{~cm}$ high.
Boundary bed 89 yields a great number of diversified microfaunas and macrofaunas that are of correlative value. The trilobites include Belgibole abruptirhachis, which also occurs immediately above the Hangenberg Schiefer interval in various cephalopodbearing sections from the Rhenish Slate Mountains (Germany), the Holy Cross Mountains (Poland), and the Carnic Alps (Austria). Although generally associated with the first sulcata, it may occur slightly earlier at Müssenberg (Sauerland, Germany) and at Grüne Schneid (Carnic Alps), Other trilobites to be found in bed 89, such as Archegonus (Phillibole) and Carbonocoryphe, are related closely to forms from the basal Tournaisian of Carboniferous time at Dalnia (Holy Cross Mountains). Dapoushang (Guizhou, China), and Grüne Schneid, everywhere occurring in cephalopod-bearing limestones. $A$. (Phillibole) drewerensis appears at a slightly younger level (bed 98). as it does in the Carnic Alps and in several sections on the northern side of the Variscan belt, as well as in south China (Dapoushang). Representatives of the shallow biodetrital facies are Brachymetopus germanicus, known from Rhineland (Germany), and a new form ("Perliproetus") that is related closely to Pudoproenus missourensis from the topmost Famennian of Devonian time in Missouri and Utah (USA), as well as to $P$. guangxiensis from the $S$. sulcata Zone at Nanbiancun (near Guilin, Guangxi, China).

The brachiopod and coral faunas are quite diverse, and the first results have been published by Legrand-Blain and Martinez Chacon (1988) and by Semenoff-Tian-Chansky (1988), respectively. These shallow-water communities, together with numerous foraminifera, such as Quasiendothyra regularis vel communis, algae, and microproblematica (Vachard, 1988), permit correlation with platform communities that are widespread on the Franco-Belgian and Russian platforms.

The mixture of pelagic elements and nearshore biotas underwent quasicontemporaneous, short-lasting transport by debris flows before lithification. As stated by Legrand-Blain and Martinez Chacon (1988) for the brachiopods, the allodapic fossils within the boundary beds show features of transport but have no signs of stratigraphic reworking. These fossils permit, in particular, direct correlation of the deeper basinal domain with the shallow-water environment of the "Kohlenkalk" platform type, As far as conodonts are concerned, only "autochthonus" basinal conodonts from the matrix are considered.

Because of its exceptional paleogeographic position under direct nearshore influence, the stratotype section shows a series of transgressive and regressive pulses that, if of eustatic origin, may be of value for correlation of earliest Carboniferous time.

\section{References}

Becker, T., Bless, M.J.M., Brauckmann, C., Friman, L., Higgs, K. Keupp, H., Korn, D., Langer, W.. Paproth, E., Racheboef, P.. Stoppel, D., Streel, M., and Zakowa, H., 1984, Hasselbachtal, the section best displaying the Devonian-Carboniferous boundary beds in the Rhenish Massif (Rheinisches Schiefergebirge): Courier Forschungsinstitut Senckenberg, y. 67, p. 181-191.

Clausen, C.-D.. Leuteritz. K. and Ziegler. W.. 1987. The eastern Provincial Quarry at Drewer (northeastern Rhenish Slate Mountains), a stratotype candidate for the Devonian/Carboniferous Boundary: Senckenbergiana Lethaea, v, 87, p. 467-477.

1989. Ausgewahlte Profile an der Devon/Karbon-Grenze im Sauerland (Rheinisches Schiefergebirge) in Amiric, G.H.B., and others, eds., Das Oberdevon des Rheinischen Schiefergebirges: Fortschritte in der Geologie von Rheinland und Westfalen, v, 35, p. 161-226. [In German.]

Cowic, J.W., Ziegler, W., Boucot, A.J., Bassett, M.G., and Remane, J., 1986. Guideline and statutes of the International Commission on Stratigraphy (ICS): Courier Forschungsinstitut Senckenberg. v. 83. p. 1-14. 
L. A SERE

\section{Montagne Noire}

- reference secilon LS-E'

o parallal sections $F, G, C O$

Siphonodelta sulcata

S. prassutcata

Bispathodus costatus

8. ziegteri muessenbergensis

Paimatole pis gracilis exmansa

$P_{\text {a }}$ pracitio goniocymeriae

Pseudopolygnathus mamburgensis trigonicus

Ps. denitheatus

Polygnathus purus subolanus

Protognathodus meischmeri

Pr. collisisoris

Pseudowaribote cf conifera

Typhioproetus sp.

Phacops so

"Perliproetus" $\mathrm{sp}$.

Archegonus (Wartople zoruptirhachis

A. (Philtibole) crispus n. $\mathrm{sp}$.

A. (Phillibole) drewerensis tatipaipebratus

Erachnmetopus germanicus

Carbonoconyphe (Winterbergla) funirena $\mathrm{n}$. sp.

Gibbusia sp.

Wochtumeria sp.

Ammonoidea civ. sp. indet.

Orbinaria? of praefaltax

Sedenticellula sp.

Orbinaria? fallax

Ovatia sp.

Rhynchopora SP.

Syringothyris sp

Spirifer ef pseudosuavis vel Tenisia sp.

Voiseyella alf. tylothyriformis

Urisoirter $\mathrm{sp}$

Voiseyerla pseudopostere

Leioproductus? aff. karmitis

Planoproducius? sp

Spinocaninifera ex gr. nigra

Somproductus sp.

Ovatia ex gr. Jaevicosta

Hemplethorhynchus sp.

Ripidiorthinchus? sp

Syringothyris aff hannibalensis

Ectocharistites? sp

Bractiythysis sp.

Motriplexus sp.

Neaxon ci, regulus

Guerichiphylism sp.

Gorizdronja ct profunda

Ufimia sp. 1

Utimia so. 2

Ufima SP. 3

Rhopatolasma sp

7 Sochkineophyflum $\mathrm{sp}$

Caninia of. tregaensis

Sutherlandia SP.

Heterophylida $\mathrm{sp}$

Cyathaxoria (Cyathocariniaj sp

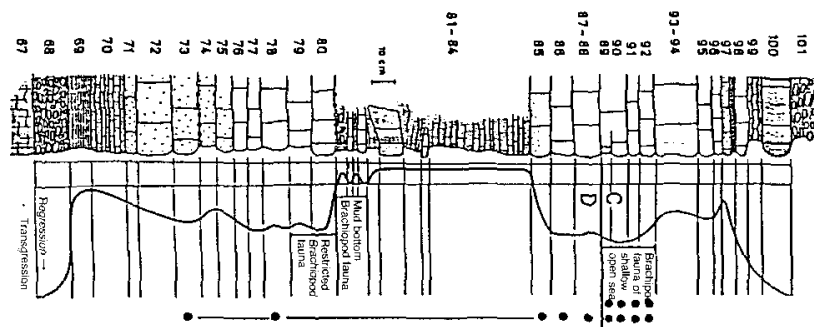

Figure 6. - Fossil content of the boundary beds in La Serre trench $E$, and environmental interpretation of some sedimentologic and faunal features (modified from Flajs and Feist, 1988; Legrand-Blain and Martinez Chacon, 1988; Semenoff-Tian-Chansky, 1988; Vachard, 1988; and additional determinations). Abbreviations: $D$, Devonian; $C$, Carboniferous; $L S, L a S e r r e ; F, G, C O$, profiles parallel to the stratotype section. See figure 2 for locations of sections. 


\section{- reference section LS-E' o parallel sections F,G,CO}

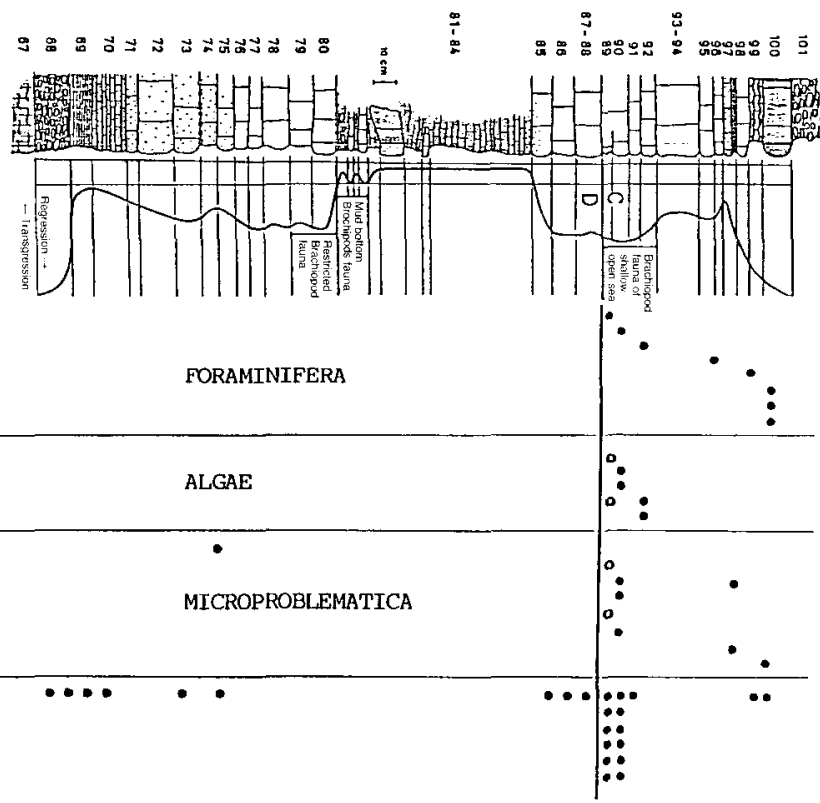

\begin{tabular}{|c|c|c|}
\hline $\begin{array}{l}\text { Quasiendothyra regulars vel communis } \\
\text { Endothyra? sp. } \\
\text { Eafandia elegans } \\
\text { Endothyra parakosvensis } \\
\text { "Tofyparnmina" sp. } \\
\text { Vicinesphaera sp. } \\
\text { Dipiosphaerina sp. } \\
\text { Bisphaera sp. }\end{array}$ & FORAMINIFERA & $\int^{-1} \cdot$ \\
\hline $\begin{array}{l}\text { Givanella of densa } \\
\text { Aphralysia ct capriorae } \\
\text { Parachaeteles cf. wissiensis } \\
\text { Hedsroomia koninckoporoides } \\
\text { Palaeoporella? sp. }\end{array}$ & ALGAE & $0_{0}^{0}$ \\
\hline $\begin{array}{l}\text { Labyrinthoconus? sp. } \\
\text { Trochiliscaceae } \\
\text { "fssinella" serrensis n. sp. } \\
\text { Umbellaceas } \\
\text { Sphaeroporella aksubaica } \\
\text { Menselina cf. magna } \\
\text { Sphaerinvia piai } \\
\text { Subkamaena ci. razdotnica }\end{array}$ & MICROPROBLEMATICA & $\int_{0}^{0}$ \\
\hline $\begin{array}{l}\text { Conchostraca } \\
\text { Pisces } \\
\text { Bryozoa } \\
\text { Gasteropoda } \\
\text { Bivalvia } \\
\text { Ostracoda }\end{array}$ & $\bullet \bullet \bullet \bullet \bullet$ & 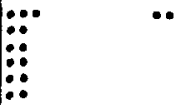 \\
\hline
\end{tabular}

Figure 6.-Continued.

Cowic. J.W.. Ziegler, W., and Remane, J., 1989, Stratigraphic commission accelerates progress, 1984 to 1989: Episodes. v. 12. p. $79-83$.

Engel, W. Feist, R., and Franke, W., 1982, Le Carbonifere antéstéphanien de la Mnntagne Noire: Rapports entre mise en place des nappes el sédimentation: Bulletin du Bureau de Recherches Goulogiques et Minieres, sectinn I, v. 4, p. 341-389. [In French.]

Feiss. R., and Flajs, G., 1987. La limite Dévonien-Carhonifere dans la Montagne Suire (France): Biostratigraphic et environnement: Comptes Rendus de lacademic des Sciences, serie 2, v 305 (20), p. $1537-$ 1544. [In Fitench.]

Flajs, G., and Feist. R., 19R8, Index conodonts, trilobites and enviromment of the Devonian-Carboniferous Boundiry beds at La Serre (Montagne Noire. Francel: Courike Forschungsinstitut Senckenberg. v. 100 . p. $53-107$

Flajs, G., Feist, R., and 7icgler, W., eds, 1988. Devonian-Carboniferous Boundary-Results of recent studics: Courier Forschungsinstitut Senckenber!. v. $1041.245 \mathrm{p}$.

Hedberg. H.D. ad., 1976, International stratigraphic gude: Nicw York, John Wiley. $200 \mathrm{p}$.

Hou, H.F., Ji, Q., Xian, J.F., and Wu, X.H., 1984, A possible stratotype of Devonian-Carboniferous boundary in Guizjou Province. South China: Cuurier Forschungsinstitut Senckentherg. ง. 67. p. 193-205.

Ji Qiang and others. 1984. The Dapoushang section: An excellent section for the Devonian-Cartomiferous boundary stratotype in Chind: Beijing: Science Press, $165 \mathrm{p}$.
Legrand-Blain, M. and Martincz Chatcon, M.L. 1988. Brachiopods at the Devonian-Carboniferous Boundary. La Serte rMontagne Noire, Hérault. France): Preliminary report: Courier Forschungsinstitut Senckenberg. v. 100. p. 1]9-127.

Puproth. E. and Strcel, M. eds. 1984. The Devonian-Cirbonifetous Boundary: Courier Forschungsinstitut Senckenberg, \&. 67, $258 \mathrm{p}$.

Sindberg, C.A., Strcel, M., and Scoll. R.A., 1972. Comparison betweer conodont ronation and spore assembtages at the DewonianCarboniferous boundary in the western and central United States and in Europe: 6e Congress Intemational Stratigraphic et de Géologie du Carbonitere, Sheftield, UK, 1967, Compte Rendu, v. 1. p. 179-203.

Schölaub, H.P., Feist, R., and Korr, D. 1988, The DevonianCarboniferous Boundary at the seetion "Grime Schneid" Carnic Alps, Austriat: A preliminury report: Courier Forsehungsinstitut Senckenterg. v. 100, p. 149-167.

Semenoff-Tian-Chansky, P., 1988, Corals from the Devonian-Carboniferous Boundary at La Serre (Montagne Noire. Francel Courier Forschungsinstitut Senckenherg, ₹. 10\%, p. 129-138.

Vachard, D., 1988, Calcareous microfossils calgae. pseudo-algac and toraminifera) from La Senc, Montagne Noire, France: Courjer Forschungsinstitur Senckenherg, 4. 100, p. 139-147.

Yu. C.M., ed, 1988. Devonian-Carboniterous Boundary in Nanbiancun. Guilin, China-Aspects and records: Beijing. Scicmec Press. 379 p. $\square$ 

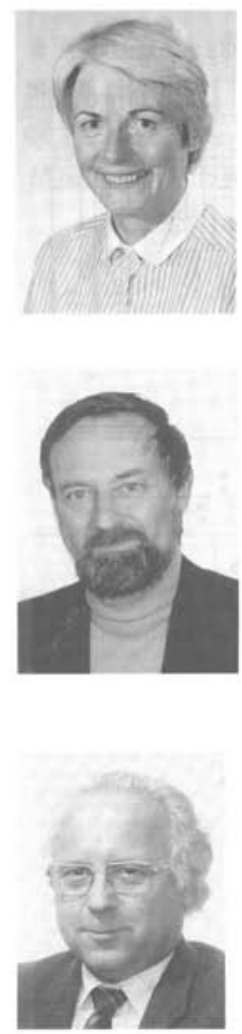

Dr. h.c. Eva Paproth previously was Chairman of the Working Group on the Devonian-Carboniferous Boundary and currently is Chairman of the Subcommission on Carboniferous Stratigraphy. She has retired recently from a geological survey in western Germany, where she concentrated on the stratigraphy of Devonian and Carboniferous strata. She is Chairman of the German geologists' institution. Bundesverband Deutscher Geologen.

Dr. Raimund Feist is a Research Paleontologist with the French $\mathrm{Na}$ tional Scientific Research Center (CNRS) at the University of Montpellier (USTL. 34095 Montpellier. France). His research concentrates on middle Palaeozoic correlation, biostratigraphy, and biofacies using especially trilobites. He is a Titular Member of the Subcommission on Devonian Stratigraphy.

Dr. Gerd Flajs is Professor of Geology and Paleontology at the Technical University of Aachen (RWTH. D-5100 Aachen, Germany). His research concentrates on middle Palae. ozoic conodont stratigraphy and carbonate microfacies, mainly in the Montagne Noire, the eastern Alps, and the Rhenish Slate Mountains. 